University at Buffalo School of Law

Digital Commons @ University at Buffalo School of Law

\title{
The Politics and Indirect Effects of Asymmetrical Bargaining Power in Free Trade Agreements
}

\author{
Meredith Kolsky Lewis \\ University at Buffalo School of Law, mlewis5@buffalo.edu
}

Follow this and additional works at: https://digitalcommons.law.buffalo.edu/book_sections

Part of the International Trade Law Commons

\section{Recommended Citation}

Meredith Kolsky Lewis, The Politics and Indirect Effects of Asymmetrical Bargaining Power in Free Trade Agreements in The Politics of International Economic Law 19 (Tomer Broude, Marc L. Busch \& Amelia Proges, eds., Cambridge University Press 2010)

This material has been published in The Politics of International Economic Law edited by Tomer Broude, Marc L. Busch \& Amelia Proges. This version is free to view and download for personal use only. Not for re-distribution, resale or use in derivative works. (c) Cambridge University Press 2011.

\section{IN COPYRIGHT}

This Book is brought to you for free and open access by the Faculty Scholarship at Digital Commons @ University at Buffalo School of Law. It has been accepted for inclusion in Contributions to Books by an authorized administrator of Digital Commons @ University at Buffalo School of Law. For more information, please contact lawscholar@buffalo.edu. 


\title{
The Politics and Indirect Effects of Asymmetrical Bargaining Power in Free Trade Agreements
}

\author{
Meredith Kolsky Lewis
}

\section{INTRODUCTION}

The World Trade Organization (WTO) has been, and continues to be, shaped in its agreements and institutional foci in significant part by political pressures emanating from its members, particularly those able to wield the most influence. Rather than being an institution with the singular focus of achieving free trade among all members, the WTO comprises a complex set of agreements, many of which represent a politically driven compromise among members as to how to manage trade rather than to liberalize it. ${ }^{1}$ Although the state of WTO liberalization reflects positions agreed to in part as a result of political realities, the reach of politics is more significant in the context of bilateral trade negotiations. Indeed, what members cannot accomplish through the WTO they may try to achieve through free trade agreements (FTAs), particularly with politically or economically weaker trade partners. In the case of the United States, FTAs have been used as an opportunity to impose provisions favored by domestic constituents - such as strengthened intellectual property provisions and labor and environment clauses - that it has not been able to get WTO members to agree to collectively in the multilateral forum. A similar phenomenon has occurred with respect to the European Union (EU)

1 See, e.g., Bagwell and Staiger, "Reciprocity, Non-Discrimination and Preferential Agreements in the Multilateral Trading System," National Bureau of Economic Research Working Paper 5932 (1997), at 1 (noting that the GATT establishes goals of reciprocity and nondiscrimination, but not of free trade).

Note: I owe thanks to the participants of the ASIL International Economic Law Interest Group 2008 Biennial Conference for their feedback on this chapter, and particularly owe gratitude to Joel Trachtman for his helpful comments. I also thank the editors and peer reviewers of this volume for their valuable suggestions. 
and its FTA partners. ${ }^{2}$ For countries with less bargaining power, the WTO's multilateral setting provides some buffer from power politics ${ }^{3}$ in the form of the consensus decision-making practice 4 and the disproportionate number of developing and least-developed countries. Countries with limited bargaining power will often find themselves in a relatively more vulnerable position in the bilateral or even plurilateral context. ${ }^{5}$ For poorer countries, this may translate into giving significant concessions in FTA negotiations out of concern that aid or other preferential treatment will be withdrawn. ${ }^{6}$

In critiquing FTAs as a negative for the multilateral trading system, commentators have addressed numerous issues, including the potential for such agreements to be more trade diverting than trade creating; 7 that FTA negotiations necessarily detract resources and attention from multilateral negotiations; ${ }^{8}$ that the plethora of regional arrangements is undermining the most-favored nation (MFN) principle; 9 and arguments that particular agreements have unfortunate

2 Harpaz, "When East Meets West: Approximation of Laws in the EU-Mediterranean Context," 43 Common Market L. Rev. (2006) 993, at 999 (discussing the expectation by the EU that in connection with its European Neighbourhood Policy, its Mediterranean neighbors will unilaterally "approximate" or align their legislation to some degree to that of the EU rather than having the parties engage in a cooperative process of give and take).

3 See Mattoo and Wunsch-Vincent, "Pre-empting Protectionism in Services: The GATS and Outsourcing," 7 J. Int'l Econ. L. (2004) 765, at 787 ("in a world of unequal bargaining power, multilaterally agreed formulae ... are likely to produce a more favourable outcome for the weaker party than bilateral negotiations.").

4 See Abbott, “A New Dominant Trade Species Emerges: Is Bilateralism a Threat?," 10 J. Int'l Econ. L. (2007) 571, at 583 (arguing that "weaker actors have a better chance to have their voices heard, and their policy choices taken into account" in the multilateral consensus-based system).

5 See, e.g., Hirsch, "The Sociology of International Economic Law: Sociological Analysis of the Regulation of Regional Agreements in the World Trading System," 19 Eur J. Int'l L. (2008) 277 , at $295-296$ (identifying the social conflict conception of international economic law as disfavoring FTAs because developing states will achieve better outcomes through the collective action of the WTO than through FTA negotiations that will reflect the power asymmetries between the parties). Bagwell and Staiger conclude that FTAs prevent the implementation of an efficient multilateral agreement based on the GATT pillars of nondiscrimination and reciprocity. See Bagwell and Staiger, "An Economic Theory of GATT," Wisconsin MadisonSocial Systems Working Paper 15 (June 1998), at 33.

6 For example, as will be subsequently discussed, the Pacific Island Forum (PIF) countries signed the PACER agreement with Australia and New Zealand in part out of fear that the latter would terminate the agreement known as SPARTECA, pursuant to which the PIF countries receive largely duty-free access to the Australian and New Zealand markets and do not have to provide preferential market access in return.

7 J. Viner, The Customs Union Issue (1950).

8 See, e.g., Abbott, supra note 4 , at 581 .

9 See, e.g., Sutherland et al., "The Future of the WTO, Addressing Institutional Challenges in the New Millenium," Report by the Consultative Board to Director-General Supachai Panitchpakdi (2005). 
terms such as TRIPS-plus provisions (where TRIPS stands for the Agreement on Trade-Related Aspects of Intellectual Property Rights). To these critiques this chapter adds an additional reason to disfavor FTAs by arguing that FTAs can have a further negative effect of constraining the future policy choices of countries that are not party to the original FTAs and therefore did not have the opportunity to negotiate or bargain with respect to terms that later end up having spillover effects on these nonparties.

This chapter argues that in addition to the direct impacts of political pressure the weaker party to an FTA experiences in the form of "take it or leave it" terms, those terms can also cause additional difficulties in an indirect way, including those for nonparties to the agreement, by effectively constraining policy choices outside the context of the original FTA. In this context "weaker members" ${ }^{\prime \prime}$ can include developed countries as well when their FTA partners are more powerful, ${ }^{11}$ as is the case with Australia relative to the United States and to some degree New Zealand relative to Australia. ${ }^{12}$

This chapter uses examples from Oceania to illustrate the negative externalities that earlier-negotiated FTAs can have on nonparties to those agreements. Using two specific regional examples as illustrations, the chapter argues that, as

10 In this chapter the term "weak" is used to describe countries with relatively less bargaining power in trade negotiations than the countries with which they are negotiating, and "strong" or "powerful" is used to describe countries with relatively more bargaining power.

"See, e.g., Abbott, supra note 4, at 571, noting that the "PTA negotiating environment strongly favors powerful economic actors like the United States and European Union, which are largely dictating terms to developing (and developed) countries." See also Harpaz, supra note 2.

${ }^{12}$ For examples of developed countries in the "weaker country" position, see, e.g., Crump, "Global Trade Policy Development in a Two-Track System," 9 J. Int"l Econ. L. (2006) 487 (identifying examples of Singapore capitulating to demands of Australia; Singapore giving in to demands of the United States; and Australia reluctantly accepting terms dictated by the United States in their respective FTA negotiations). Crump provides a useful example in the context of the types of rules of origin (ROO) provisions chosen in various FTAs. In 1983, New Zealand and Australia chose a value-added ROO system for their trade agreement (the Australia New Zealand Closer Economic Relationship Trade Agreement, or ANZCERTA). Subsequently, when Australia negotiated its FTA with Singapore, Singapore pushed for a change in tariff classification or transformation measure for ROO, but Australia insisted on the value-added ROO methodology used in ANZCERTA. On the flip side, when Australia later negotiated its FTA with the United States and was the weaker of the two parties, it capitulated to U.S. demands for the type of ROO methodology Australia had rejected when it had been proposed by Singapore. Ibid., at 502. The phenomenon of FTA provisions having spillover effects for others is akin to findings of "regulatory export" from stronger to weaker countries, in which the United States and the EU tend to be the exporters and a wide range of other countries the importers. See, e.g., Raustiala, "The Architecture of International Cooperation: Transgovernmental Networks \& the Future of International Law," 43 Va. I. Int'l L. (2002) 1; Slaughter, "Sovereignty and Power in a Networked World Order," 40 Stan. J. Int'l L. (2004) 283 , at 293-297 (discussing Raustiala's findings). 
a result of the power imbalances in many FTA negotiations and of path dependence among FTAs, the terms agreed to in earlier FTAs can subsequently constrain negotiating space and policy options for other trading partners and political allies. ${ }^{13}$

In the first case, Australia succumbed to the United States' superior bargaining power in the Australia-United States Free Trade Agreement (AUSFTA) ${ }^{14}$ negotiations by agreeing to various exceptions to liberalization commitments and to terms with which it was not happy. The success of U.S. pressure has resulted in changes in Australian law. Although these changes clearly have direct effects on Australia, they also have repercussions for New Zealand, because under the Australia-New Zealand Closer Economic Relations Trade Agreement (ANZCERTA or CER) and related treaties, ${ }^{15}$ Australia and New Zealand engage jointly in certain regulatory activities and seek broadly to create a harmonized business environment. ${ }^{16}$ Thus, Australia's agreement under the AUSFTA to impose heightened intellectual property protections and to enact regulations on pharmaceuticals has potential indirect effects on New Zealand, which does not impose such protections or regulations. Although New Zealand would not otherwise adopt such regulations, it will now be futile on the part of New Zealand to try to persuade Australia to revert to its previous regulations, because of the bind established by the AUSFTA terms all but imposed by the United States. ${ }^{17}$

In the second illustrative case, Pacific Island Forum (PIF) members have very little bargaining power relative to Australia and New Zealand, and they have had agreement terms essentially dictated to them by their larger, wealthier neighbors. ${ }^{18}$ The terms of the Pacific Agreement on Closer Economic Relations (PACER) ${ }^{19}$ are now resulting in the PIF countries' experiencing pressure

13 In addition to these effects there are, of course, the more visible examples of U.S.- or EU-drafted template agreements being virtually imposed upon future generations of partners to trade and investment agreements.

4 Australia-United States Free Trade Agreement (AUSFTA), WT/REG184, entry into force January $1,2005$.

15 The ANZCERTA comprises a number of instruments, including the Trans-Tasman Mutual Recognition Arrangement, the Trans-Tasman Travel Arrangement, and several other documents; these may be accessed at http://www.mfat.govt.nz/Foreign-Relations/Australia/1-CER/ o-cer-timeline.php.

16 Australia New Zealand Closer Economic Relations Trade Agreement (ANZCERTA), WT/REGil1, entry into force January 1,1983 .

${ }_{77}$ This can also be seen as a form of path dependence. For a discussion of sequencing path dependence see Hathaway, "Path Dependence in the Law: The Course and Pattern of Legal Change in a Common Law System," 86 lowa L. Rev. (2001) 601, at 617-622.

18 In particular the Pacific Agreement on Closer Economic Relations, discussed herein.

19 See the Pacific Agreement on Closer Economic Relations, made at Nauru, August 18, 2001, entry into force October 3, 2002, which is discussed herein. PACER is an umbrella agreement 
from these traditional allies ${ }^{20}$ and are constraining the PIF countries in deciding how to approach negotiations with the $\mathrm{EU}$ to form potential economic partnership agreements. ${ }^{21}$

The negative externalities that result when FTA terms are imposed by stronger FTA partners on weaker ones create legitimacy concerns about FTAs above and beyond those already identified in the literature. It is problematic that countries not party to an FTA or its negotiations nonetheless find their policy options negatively constrained. This is an issue the WTO has not considered, but it would be worthy of attention in the context of attempting to reform General Agreement on Tariffs and Trade (GATT) Article XXIV.

\section{THE AUSFTA AND ITS INDIRECT IMPLICATIONS FOR NEW ZEALAND}

After several years of negotiations, the AUSFTA came into effect on January 1 , 2005. Although the agreement was widely supported by Australian businesses, the negotiating process ${ }^{22}$ and substantive provisions have been criticized on a number of grounds. The most frequent criticisms have been addressed at the TRIPS-plus intellectual property provisions the AUSFTA contains, provisions relating to Australia's Pharmaceutical Benefits Scheme, and the effects these provisions collectively may have on the availability of low-cost pharmaceutical products in Australia. ${ }^{23}$ However, the agreement has also been criticized more

rather than an FTA itself. It contains provisions relating to the formation of the Pacific Island Countries Trade Agreement (PICTA), and in this way Australia and New Zealand, although not parties to PICTA, have influenced that agreement by means of the PACER Agreement. For the text of PACER see http://www.forumsec.org/UserFiles/File/PACER.Text.pdf.

20 See generally Kelsey, "Big Brothers Behaving Badly: The Implications for the Pacific Islands of the Pacific Agreement on Closer Economic Relations (PACER)," Interim Report, commissioned by the Pacific Network on Globalisation (2004).

21 See Part III of this chapter.

22 See, e.g., Mitchell, “The Australia-United States Free Trade Agreement," in Laurence Boulle et al. (eds.), Challenges to Multilateral Trade: The Impact of Bilateral, Preferential and Regional Agreements (2008) 115, at 117-118 (criticizing the limited parliamentary scrutiny treaties receive in Australia, and the limited role interested stakeholders had in the treaty negotiating process).

23 See, e.g., Faunce, Johnston, and Bambrick, "The Trans-Tasman Therapeutic Products Authority: Potential AUSFTA Impacts on Safety and Cost-Effectiveness Regulation for Medicines and Medical Devices in New Zealand," 37 Victoria U. Wellington L. Rev. (2006) 365 (hereinafter Faunce et al., "Trans-Tasman"); Faunce and Lexchin, "'Linkage' Pharmaceutical Evergreening in Canada and Australia," 4:8 Australia and New Zealand Health Policy (2007), accessible at http://www.anzhealthpolicy.com/content $/ 4 / 1 / 8$ (hereinafter Faunce and Lexchin, "Evergreening"); Mercurio, "The Impact of the Australia-United States Free Trade Agreement on the Provision of Health Services in Australia," 26 Whittier L. Rev. (2005) 1051; Chalmers, "Evergreen or Deciduous? Australian Trends in Relation to the 'Evergreening' of Patents," 30 Melb. 
generally as being a bad deal for Australia. Andrew Mitchell put it bluntly:

The AUSFTA provides an illustration of the outcomes that countries with relatively little bargaining and economic power can expect from an FTA with the US. It also serves as a warning of how even an economically successful developed country may end up sacrificing its welfare, public policies, and democratic processes in a dogged pursuit to cement relations with the United States, in a manner that would be unlikely in the vigorous negotiating environment of the WTO. ${ }^{24}$

One might dismiss such criticisms on the basis that Australia was aware of its limited bargaining power and nonetheless determined that it was worthwhile to enter into an FTA with the United States, even though it had to accept certain terms it did not like. Although this may be the case, this chapter focuses on a separate point: that Australia's decision to accept the U.S.'s terms in the AUSFTA affects not just Australia but also its neighbor across the Tasman. To the extent that the AUSFTA results in higher prices for pharmaceuticals in Australia, for example, New Zealanders' access to affordable pharmaceuticals is also potentially at stake as a result of the relationship between Australia and New Zealand that was established in the Australia-New Zealand CER and its flow-on agreements. In particular, because Australia has committed to certain provisions in the AUSFTA, it will seek to have relevant arrangements with New Zealand conform to its existing commitments. New Zealand is thus a victim of path-dependent externalities in the form of regulations Australia has agreed to adopt by virtue of its negotiations with the United States - negotiations in which New Zealand had no opportunity to participate.

\section{A. AUSFTA and Pharmaceuticals Trade}

The AUSFTA has the potential to affect Australian pharmaceutical prices in a couple of ways. First, certain TRIPS-plus intellectual property provisions have implications for medicines. ${ }^{25}$ In particular, relative to TRIPS, the agreement

U. L. Rev. (2006) 29; Kingsbury, "Intellectual Property Provisions in Bilateral and Regional Free Trade Agreements: What Should New Zealand Expect from a New Zealand/United States Free Trade Agreement?," 10 NZ Bus. L. Q. (2004) 222.

24 Mitchell, supra note 21 , at 116.

25 The AUSFTA intellectual property commitments are in Chapter 17 of the agreement and in accompanying side letters. Provisions with specific implications for the provision of low-cost medicines include AUSFTA Art 17.9.8 (effectively extending the patent term for pharmaceuticals); AUSFTA Art. 17.9.7 (limiting compulsory licensing of patented pharmaceuticals to the extent provided in TRIPS); and AUSFTA Art. 17.9.4 (limiting parallel importing). Sce also Kingsbury, supra note 23 , at 233 . 
provides narrower avenues for allowing compulsory licensing; an expanded scope for what is patentable; and minimum and extended terms of data protection and data exclusivity. It also prohibits parallel importation. ${ }^{26}$ It additionally contains an "evergreening" notification provision, ${ }^{27}$ which requires that drug manufacturers be notified of any upcoming generic drug entry into the market, and further requires that approval be denied to such generic drugs when a patent is "claimed" by a manufacturer that has not "consented or acquiesced" to the entry into the market of the generic drug. ${ }^{28}$ Although Australia introduced anti-evergreening provisions along with the AUSFTA implementing legislation to combat the possibility that this provision would lead to an increase in drug prices, such provisions were strongly criticized by the United States and it remains to be seen what would happen if a dispute arose over the operation of the Pharmaceutical Benefits Scheme. ${ }^{29}$

In addition to the TRIPS-plus provisions, the AUSFTA requires regulatory dialogue between the U.S. Food and Drug Administration and the Australian Therapeutic Goods Association to speed up approvals of "innovative" medical products and emphasizes a linkage between innovation and highquality health care. $3^{\circ}$ Pursuant to AUSFTA, Australia had to make changes to the Pharmaceutical Benefits Scheme, including adding a review procedure of the Pharmaceutical Benefits Advisory Committee (PBAC) drug-listing rejections. ${ }^{31}$ Although no changes were directly required to Australia's system of reference pricing, the United States had as a negotiating goal that that system be dismantled..$^{32}$ Because of this, concerns have been raised that the combination of the various requirements will ultimately force Australia to abandon this cost-effective measure of setting drug prices. ${ }^{33}$ Prescription Medicines in the United States and Australia," 35 I. L. Med. E Ethics (2007) 643, at 650 n. 50 .

27 AUSFTA Art. 17.10.4(a) and (b).

28 Ibid.; see also Faunce et al., "Trans-Tasman," supra note 23, at 368-369 for a discussion of evergreening.

29 Faunce et al., "Trans-Tasman," supra note 23, at 371-372. In the event a dispute were to arise, Faunce argues that to the extent the AUSFTA is textually ambiguous, Australia could rely on the anti-evergreening amendments as evidence of its expectation that Art. 17.10.4 would not lead to higher pharmaceutical prices under the Pharmaceutical Benefits Scheme. See ibid. for a discussion of the merits of the potential legal arguments that could be raised.

30 AUSFTA Annex $2 \mathrm{C}(1), 2 \mathrm{C}(4)$.

${ }^{31}$ Faunce, "Reference Pricing for Pharmaceuticals: Is the Australia-United States Free Trade Agreement Affecting Australia's Pharmaceutical Benefits Scheme?," 187:4 Med. J. Australia (2007) 240 , at 240-242.

32 Ibid.

33 Ibid. 


\section{B. CER - A Unique Relationship}

Australia and New Zealand have a long history of economic partnership. They entered into a limited trade agreement in $1933,{ }^{34}$ and they subsequently formed the original "NAFTA" - the New Zealand Australia Free Trade Agreement - in $1965^{\circ} .35$ This agreement removed 80 percent of the tariffs on trans-Tasman trade, but some restrictions remained. The remaining barriers included Australia's closed market for New Zealand dairy products and New Zealand's quantitative restrictions and various export incentives. In the early 1980s, agreement was finally reached to remove these obstacles and the countries entered into the highly comprehensive ANZCERTA (commonly referred to as CER) in 1983.

The parties subsequently entered into a protocol to accelerate the removal of all tariff barriers by 1990 , which was a number of years earlier than called for in the CER Agreement. ${ }^{36}$ In connection with CER, the two countries have gone well beyond tariff liberalization and have contemplated - and in some cases already enacted - various forms of regulatory harmonization with respect to customs and quarantine procedures. ${ }^{37}$ In 1993, the two countries entered into the Trans-Tasman Mutual Recognition Arrangement (TTMRA), which provides (subject to limited exceptions) that goods that may lawfully be sold in either country may be lawfully sold in the other, $3^{8}$ and (also subject to limited exceptions) that an individual licensed to practice a given occupation in one of the countries is entitled to practice the equivalent occupation in the other country. ${ }^{39}$ Although therapeutic goods legislation (such as Australia's Therapeutic Goods Act 1989 and New Zealand's Medicines Act 1981) is currently exempted from the TTMRA, the TTMRA provides that it is a goal to ultimately incorporate therapeutic goods into the agreement.

CER is a unique arrangement, among other reasons, because it has led to a significant degree of harmonization between Australia and New Zealand. $4^{\circ}$

34 Trade Agreement of September 5, 1933.

35 New Zealand Australia Free Trade Agreement, August 31, 1965.

$3^{6}$ Protocol to the Australia New Zealand Closer Economic Relations Trade Agreement on Acceleration of Free Trade in Goods, Art. 1.1.

37 See, e.g., Exchange of Letters and Joint Understanding of Harmonisation of Customs Policies and Procedures, August 16, 1988; Protocol on Harmonisation of Quarantine Administrative Procedures to the Australia New Zealand Closer Economic Relations Trade Agreement, August 18, 1988.

$3^{8}$ Trans-Tasman Mutual Recognition Arrangement Part IV, accessible at http://www.dfat.gov .au/geo/new_zealand/ttmra.pdf.

39 Ibid., Part V.

$4^{\circ}$ See, e.g., Rennie, "Competition Provisions in Free Trade Agreements: Unique Responses to Bilateral Needs or Derivative Developments in International Competition Policy," 15 Int. T.L.R. (2009) 57 , at 64 (noting unique hamonization provisions of ANZCERTA). 
It was formed with the belief that agreeing to joint procedures and practices would reduce transaction costs and enhance economic growth for both economies. Although there is often an expectation that the unified practice will more strongly resemble whatever Australia's system has been, rather than New Zealand's, ${ }^{4+}$ New Zealand presumably has been willing to accept this bias in the instances where it has signed on to specific harmonization measures, in part because of the similarities between Australia and New Zealand's regulatory approaches. However, New Zealand would have made its decisions based on Australia's regulatory standards and procedures at the time. New Zealand likely would not have contemplated that Australia would subsequently significantly alter certain parts of its regulatory framework pursuant to a future FTA, rendering aspects of its regulatory structure significantly different from their previously similar approach. Nevertheless, because of New Zealand's relatively weaker position with respect to Australia - and Australia's relative lack of bargaining power vis-à-vis the United States - Australia accepted the terms of AUSFT'A notwithstanding its commitments under ANZCERTA and the implicit assumptions (of similar regulatory approaches) underlying those commitments.

\section{AUSFTA Implications for New Zealand}

As already noted, Australia and New Zealand have engaged in a range of harmonization efforts as a result of specific CER commitments or more indirectly as a result of the general integration goal of CER. To the extent that Australia has changed or will change certain of its regulatory frameworks pursuant to its obligations under the AUSFTA, New Zealand may find itself under pressure to do the same in the future. The most salient example of this phenomenon lies in the context of the regulation of therapeutic products (comprising medicines, medical devices, and complementary medicines and dietary supplements that have therapeutic uses). $4^{2}$

In December 2003, New Zealand and Australia entered into an agreement to negotiate the creation of a joint agency to be called the Australia New Zealand Therapeutic Products Authority (ANZTPA), which would replace Australia's Therapeutic Goods Authority and New Zealand's equivalent, the Medicines and Medical Devices Safety Authority (known as Medsafe). ${ }^{43}$ ANZTPA would

4 Compare Harpaz, supra note 2, with respect to EC-Israel relations.

42 See generally Faunce et al., "Trans-Tasman," supra note 23.

43 Agreement between the Government of Australia and the Government of New Zealand for the Establishment of a Joint Scheme for the Regulation of Therapeutic Products (September 9, 2003), accessible at http://www.anztpa.org/about/treatytext.pdf. 
create harmonized regulations for therapeutic products that would apply to both countries. An eventual ANZTPA has been seen by both countries as "a significant step in the further development of a single economic market." 44

ANZTPA was to have been created by 2006, but the New Zealand Labourled government (which was subsequently replaced in 2008 with a Nationalled coalition) did not have the numbers necessary in Parliament to pass a version of the requisite legislation that would satisfy all interested parties. ${ }^{45}$ In 2007 , the project was officially placed on hold. $4^{6}$ Nonetheless, the original agreement remains in place and the bill will be revisited once sufficient votes are available. 47

In this context, significant concern was voiced in New Zealand that ANZTPA would inherit the heightened intellectual property obligations and pharmaceutical manufacturer protections that the United States imposed on Australia's Therapeutic Goods Authority by means of the AUSFTA..$^{8}$ New Zealand's Health Committee raised these concerns - and those of New Zealand's Pharmaceutical Management Agency (Pharmac) - in its 2004 report on ANZTPA:49

Pharmac noted a number of concerns ... including possible increases in the cost of generic drugs ... and possible increases in patent terms for medicines. In its written submission to us, Pharmac noted that ... the cost of these latter increases as a flow-on effect of the free trade agreement between Australia and the United States of America could amount to between $\$ 85$ million and $\$ 135$ million over 3 years.

As of this writing, it remains to be seen whether Pharmac and the New Zealand Health Committee's concerns will keep ANZTPA on the back burner

44 See "Australia and New Zealand Closer Economic Relations (CER) Ministerial Communique" (December 11, 2004), accessible at http://www.dfat.gov.au/geo/new_zealand/anz_ cer/cer_communique_2004html.

45 New Zealand has a Mixed Member Proportional representation system of government similar to that used in Germany. Therefore unless one political party wins an absolute majority of seats, there is a coalition government comprising two or more parties. Although the members of the coalition will often vote together, this is not the case on every issue. See, e.g., http://www. elections.org.nz/voting/mmp/.

$4^{6}$ State Services Minister Annette King, “Therapeutics Products and Medicines Bill on Hold," Press Release (July 16, 2007), accessible at Http:/Www.Beehive.Govt.Nz/Release/ Therapeutics+Products+And+Medicines+Bill+Hold.

47 Ibid.

$4^{8}$ Faunce et al., "Trans-Tasman," supra note 23, at 367.

49 New Zealand Health Committee, "International Treaty Examination of the Agreement Between the Government of New Zealand and the Government of Australia for the Establishment of a Joint Scheme for the Regulation of Therapeutic Products," (June 2004) 3, quoted in Faunce et al., "Trans-Tasman," supra note 23 , at 367. 
indefinitely. Given the support among some members of Parliament, it seems more likely that at some point the legislation will be passed, the treaty signed, and ANZTPA will become a reality. However, in either case, the terms the United States extracted from Australia in the AUSFTA will affect New Zealand. If plans for ANZTPA were scuttled as a result of the AUSFTA, this would mean that New Zealand felt it had to abandon a harmonization effort it otherwise intended to pursue. If, as is more likely, ANZTPA ultimately comes into being, the effects for New Zealand may be more significant, because it might need to adopt the AUSFTA standards to effectuate the authority - and see costs increase as a result. The political reality for New Zealand is, unfortunately, that Australia will likely be able to dictate the terms of ANZTPA by virtue of its preexisting commitments under the AUSFTA - commitments to a trading partner more powerful than New Zealand. This is a concrete example of a negotiation phenomenon that Oona Hathaway has explained in terms of sequencing path dependence: "The power to set the agenda can thus become, in a very real sense, the power to determine the result." 50

Thus, in the absence of AUSFTA, New Zealand and Australia had similar regulatory approaches to pharmaceuticals and likely could have harmonized their regulatory schemes relatively easily. Now, however, New Zealand finds itself in a very different situation as a result of the spillover effects of the AUSFTA - an agreement to which it is not a party, in which it had no negotiating role, and from which it receives no benefits.

New Zealand may be faced with preordained AUSFTA terms in a different context as well. The United States is currently seeking to join the TransPacific Strategic Economic Partnership Agreement (also known as the $\mathrm{P}_{-4}$ Agreement), which now comprises New Zealand, Chile, Singapore, and Brunei Darussalam..$^{51}$ Initial negotiations on financial services and investment have already been conducted. Further negotiations, geared toward having the United States join the agreement in its entirety, as well as the additional participation of Australia and Peru, were scheduled to occur in March 2009. These negotiations have been put on hold temporarily while the Obama administration conducts a review of its trade policy and decides which of the various FTA negotiations initiated by the Bush administration it wishes to continue to pursue. Although these negotiations have therefore been temporarily delayed, it seems likely this is merely procedural and that the Obama administration will decide to resume the negotiations. With the United States already having

50 Hathaway, supra note 17 , at 618-619.

${ }^{51}$ The Trans-Pacific Strategic Economic Partnership Agreement, WT/REG229 S/C/N/394, entry into force May $28,2006$. 
concluded FTAs with Australia, Peru, Chile, and Singapore, it seems highly likely that the United States will expect New Zealand and Brunei Darussalam to agree to at least some of the measures found in the FTAs the United States has with the other expanded $\mathrm{P}_{-4}$ agreement partners. ${ }^{52}$

The AUSFTA therefore provides an example of an FTA in which the weaker party, Australia, has capitulated to TRIPS-plus provision and other terms that WTO members collectively have successfully resisted incorporating into multilateral trade agreements. This may be a bargained-for exchange in the case of Australia and the gains it sought to obtain under the AUSFTA, but the bargaining process did not take into account the negative externalities of these terms impacting New Zealand. It is problematic that New Zealand finds itself with unexpected, undesirable regulatory choices as a result of political power being exercised in an agreement it had no role in negotiating.

Although New Zealand may be the victim of path dependence and FTA politics in the case of flow-on effects of the AUSFTA or in the case of the P-4 expansion, it is on the other side of the equation in the role of a "big brother behaving badly" 53 in the context of the Pacific region, as is discussed in the following section.

\section{PICTA, PACER, AND THE ECONOMIC PARTNERSHIP AGREEMENTS: PACIFIC ISLANDS NATIONS BETWEEN A ROCK AND A HARD PLACE}

Pacific Islands countries have had historical ties to Europe as a result of colonization, and to Australia and New Zealand largely as a result of sheer proximity.54 Many countries in the Pacific are a part of the ACP group of countries (Africa, Caribbean, and the Pacific) that comprise former European colonies. The ACP group historically benefited from preferential access to European markets based on the colonial relationships. However, providing preferential access to former colonies to the exclusion of other developing countries was recognized to be a violation of the MFN principle enshrined

$5^{2}$ Rennie, supra note $4^{\circ}$, at 71 (noting the path-dependent nature of bilateral FTA provisions whereby terms become a reflection of common practice rather than the particular needs of the parties). In the case of pharmaceuticals protection, the United States has negotiated similar terms to the AUSFTA provisions in its FTA with Korea.

53 See, generally, Kelsey, supra note 20 .

54 The Cook Islands, Niue, and Tokelau are part of the Realm of New Zealand. The Cook Islands and Niue are in free association with New Zealand. Tokelau has taken steps toward free association but has less autonomy than the Cooks or Niue. See http://www.gg.govt.nz/role/constofnz. htm for information regarding New Zealand's constitutional structure. 
in GATT Article I. Article I provides in relevant part that "any advantage, favour, privilege or immunity granted by any contracting party to any product originating in or destined for any other country shall be accorded immediately and unconditionally to the like product originating in or destined for the territories of all other contracting parties." 55 It is inconsistent with the MFN principle for Europe to give preferential tariff access to ACP countries while not providing this same access to other WTO members. ${ }^{56}$ Furthermore, providing the ACP countries with comprehensive market access to the EU under the arrangements established under the Lome Conventions did not create a free trade area or areas pursuant to Article XXIV because of the nonreciprocal nature of the arrangements. ${ }^{5}$

As a result of the MFN-inconsistent nature of the historical preferences, the EU sought and successfully received a waiver from the GATT and later the WTO that permitted it to maintain its preferential treatment of the ACP countries notwithstanding its obligations pursuant to Article I GATT, within the Lomé framework. This waiver was extended in 2000 , but it ultimately expired in December 2007. As a result, the EU, on the one hand, and the ACP countries, on the other, have had to decide what, if anything, will replace the historical preferences. Without any new agreements, the waiver would expire and the EU would then need to apply its tariff schedules on an MFN basis with respect to the ACP countries. Although other exceptions would apply in certain instances and for certain products by means of the Generalized System of Preferences (GSP) schemes for developing countries and Europe's Everything but Arms program for least developed countries, this coverage would not be comprehensive. For example, sugar, which is one of Fiji's most important exports and which is currently the subject of a protocol to promote such

55 General Agreement on Tariffs and Trade (GATT) Art. I.l.

56 The long-running EC-Bananas dispute has highlighted this inconsistency. See "European Communities - Regime for the Importation, Sale and Distribution of Bananas," WTO Doc. WT/DS27/R/USA (May 22, 1997), panel report.

57 The EC had also attempted to argue to the contrary in the second GATT panel examination of the EC's bananas program. The panel (whose report was not adopted) stated that the lack of reciprocal trade liberalization obligations made the Lomé Convention arrangements "substantially different from those of a free trade area, as defined in the Article XXIV:8(b)." See "EEC - Import Regime for Bananas," WTO Doc. DS $38 / R$ (February 11, 1994), panel report, para. 159. The panel noted that if such arrangements did fall within Article XXIV:8(b) there would have been little need for the contracting parties to reach decisions regarding Generalized System of Preferences schemes and the Enabling Clause. Ibid., para. 162. For a detailed discussion of the GATT-era panel reports in the Bananas dispute, see J. H. Mathis, Regional Trade Agreements in the GATTWTO:Article XXIV and the Internal Trade Requirement (2002), at $88-97$. 
exports, ${ }^{8}$ is not included in the EU's GSP scheme. ${ }^{59}$ Rather than broaden its. GSP scheme coverage to enable the ACP countries to maintain their nonreciprocal market access to the EU, the EU instead proposed that it enter into a series of economic partnership agreements (EPAs) with the ACP countries (in six regional groups) ${ }^{60}$ to take the place of the waiver. The concept was that the EPAs would satisfy the definition of free trade areas under GATT Article XXIV, ${ }^{61}$ and therefore the tariff treatment granted under such agreements would not need to be extended to other WTO members on an MFN basis and would not be subject to waiver approval. Thus the ACP countries would be able to maintain their existing preferential access to the EU market.

A difficulty for the ACP countries, however, has been that acceding to the EPAs would require them to provide substantial, comprehensive market access to the EU. Previously, under the waiver, the EU provided preferential market access to the ACP states, but it did not demand reciprocal market access in return. Thus, the ACP countries have been faced with a choice: Should they sacrifice their preferential access to the European Union but maintain their own tariffs on goods originating from its members, or should they instead opt to enter an EPA, thus formalizing their preferential access to the European Union but at the cost of having to provide significant new market access in return? $?^{62}$

To complicate matters further for Pacific Island countries, once the EU made clear its intention to replace ACP preferences with reciprocal trade arrangements in the form of EPAs, Australia and New Zealand orchestrated the Pacific Agreement on Closer Economic Relations, known as PACER, which

$5^{8}$ The ACP/EU Sugar Protocol is an agreement by which the EU agrees to purchase set quantities of sugar from the ACP countries. It was originally annexed to the Fourth ACP/EU Lomé Convention. Upon the expiry of the Lomé Convention, the protocol was subsequently incorporated into the Cotonou Partnership Agreement, June 23, 2000.

59 See, e.g., Curran, "Response to the Article 'Are the Economic Partnership Agreements a FirstBest Outcome for the ACP Countries?' Perez, R. (2006) 40(6)," 41 JWT (2007) 243, at 244 (noting that certain products important to ACP countries are excluded even from proposed GSP-plus formulations).

60 There is a Caribbean group, Central African group, East and Southern African Group, South Africa Development Community group, West African group, and a Pacific group.

6. Article XXIV:8(b) defines a free trade area as "a group of two or more customs territories in which the duties and other restrictive regulations of commerce ... are eliminated on substantially all the trade between the constituent territories in products originating in such territories."

62 One analysis has suggested that ACP countries would be better off declining to enter into EPAs and relying instead on the EU's GSP scheme (in the case of developing countries) and Everything but Arms program (in the case of least developed countries). See Perez, "Are the Economic Partnership Agreements a First-Best Optimum for the African Caribbean Pacific Countries?," 4o JWT (2006) 999. 
calls for fundamental changes to the relationship between the Pacific Islands Forum or PIF countries on the one hand and Australia and New Zealand on the other. If an EPA with the EU is entered into, the PIF countries will likely trigger obligations under PACER to begin negotiating an FTA with Australia and New Zealand. Indeed, several meetings of the PACER parties were held in 2008 and 2009 to discuss when and how to commence negotiations for a future agreement, which is being referred to as "PACER-Plus." ${ }_{3}$

The PIF countries have reason to want to avoid triggering these negotiations. Although the Pacific's imports from Europe are not particularly substantial, ${ }^{64}$ they are much more significant from Australia and New Zealand. For example, in 2007, New Zealand exported NZ \$786.5 million in merchandise to PIF countries. ${ }^{65}$ Likewise, Australia's exports to the Pacific are substantial and significantly in excess of its imports from the region. ${ }^{66}$ It has been predicted that, should the PIF countries have to lower their tariffs on goods entering from New Zealand and Australia, there will be significant losses of revenue. This lost tariff income - estimated as approximately U.S. \$110 million - will represent losses of up to 12 to 19 percent of national income for some PIF countries. ${ }^{67}$ In addition, some forecast that upward of 75 percent of Pacific manufacturing will have to cease operations under PACER-Plus. ${ }^{68}$

\section{A. Historical Preferences from Australia and New Zealand}

Not unlike the arrangements the EU had with the ACP countries pursuant to the Lomé Conventions, New Zealand and Australia have long been providing

63 For a discussion of these meetings see Pacific Institute of Public Policy, "PACER Plus: The Art of Negotiation," Briefing Paper (May 2009), accessible at www.pacificpolicy.org.

64 Approximately 3 percent of Pacific imports come from the EU. See the European Commission, Directorate-General for Trade and Directorate-General for Development, "Trading for Development: An European Union-Pacific Economic Partnership Agreement," (2007), at 5 , accessible at http://trade.ec.europa.eu/doclib/docs/2007/june/tradoc_134815.pdf.

65 Nearly half of this total went to Fiji. See Ministry of Foreign Affairs and Trade, "Key Pacific Issues - Trade" (August 20, 2009), accessible at www.mfat.govt.nz/Foreign-Relations/ Pacific/Trade/index.php.

66 Close to half of the Solomon Islands' imports come from Australia; in 2001-2002 this represented AU $\$ 64$ million in trade, whereas the Solomons only exported AU \$2 million in merchandise to Australia. In 2002-2003, Australia exported AU $\$ 38$ million to Kiribati but only imported a negligible AU $\$ 285,000$ in merchandise from Kiribati. See Kim, "Howard's Pacific Colonialism: Who Benefits?,".Centre for Research on Globalisation-Global Research (July 27, 2005), accessible at http://www.globalresearch.ca/index.php?context=va\&aid=742.

67 Ibid., at 2.

68 See, e.g., Cordemans, "Pacific Islands Bullied by Australian, NZ Trade Officials, Say Experts," The Epoch Times (May 30, 2009, quoting Pacific Network on Globalisation statements that 80 percent of manufacturing could close down). 
preferential treatment to Pacific Island countries. The South Pacific Regional Trade and Economic Cooperation Agreement (SPARTECA), which came into force in 1981 , is a nonreciprocal agreement among the members of the South Pacific Forum ${ }^{6}$ that provides duty-free access into Australia and New Zealand markets for goods from PIF members. ${ }^{70}$

It is unclear how it came to pass that SPARTECA was able to be notified to the GATT as a partial scope agreement pursuant to the Enabling Clause. ${ }^{71}$ The Enabling Clause allows for certain arrangements that would not otherwise be permissible under GATT Article XXIV. In particular, the Enabling Clause is the legal basis in the WTO for GSP schemes. It also permits regional arrangements among developing countries, and the Global System of Trade Preferences pursuant to which various developing countries provide reciprocal trade concessions to one another..$^{2}$ However, the Enabling Clause does not permit agreements whereby developed countries give nonreciprocal preferences to subsets of developing countries, outside of the GSP context. This has been precisely the problem with the EC's long-standing preferences granted to the ACP states, and why waivers have been necessary in order for the EC to provide preferential, nonreciprocal treatment to the ACP countries..$^{73}$

Notwithstanding the scope of the Enabling Clause, however, SPARTECA was notified pursuant to the Enabling Clause even though it involves the developed member countries of Australia and New Zealand providing nonreciprocal preferential market access only to the Pacific Island countries. Unlike the EC's Lomé and Cotonou arrangements, there is no apparent expiration

69 The original members of SPARTECA were Australia, New Zealand, and the members of the South Pacific Forum - the Cook Islands, Fiji, Kiribati, Nauru, Niue, Papua New Guinea, Solomon Islands, Tonga, Tuvalu, and Western Samoa. SPARTECA Article XIV.1.

$7^{\circ}$ The text of SPARTECA may be found at, inter alia, http://www.worldtradelaw.net/ta/ agreements/spartecafta.pdf.

71 "SPARTECA Enabling Clause Preferential Arrangement," GATT Doc. L/5100 (February 20, 1981).

72 "Decision on Differential and More Favourable Treatment, Reciprocity and Fuller Participation of Developing Countries," GATT Doc. L/4903, BISD 26S/203 (November 28, 1979).

73 The initial waiver was granted by the GATT contracting parties on December 9, 1994, just prior to the entry into effect of the WTO, to the preferences the EU was granting to ACP countries pursuant to the Fourth Lome Convention. This waiver was extended on October 14, 1995 until February 29, 2000, "EC - The Fourth ACP-EC Convention of Lome - Extension of Waiver - Decision of ${ }_{14}$ October 1996," WTO Doc. WT/L/186 (October 18, 1996). At the Doha Ministerial Conference a further waiver was granted to permit the EU to continue providing preferences pursuant to the interim Cotonou Agreement until December 31, 2007; "Ministerial Conference - Fourth Session - Doha, 9-14 November 2001 - European Communities - The ACP-EC Partnership Agreement - Decision of 14 November 2001," WTO Doc. WT/MIN(o1)/15 (November 14, 2001). See also Nwobike, "The Emerging Trade Regime under the Cotonou Partnership Agreement: Its Human Rights Implications," 40 JWT (2006) 291, at 294 ก. 24. 
date for SPARTECA's status. ${ }^{74}$ Thus, for many years the PIF countries have received unilateral trade preferences from Australia and New Zealand. Once it became clear the EU was going to attempt to negotiate EPAs with the Pacific ACP countries, however, Australia and New Zealand developed an interest in reciprocal relationships as well.

\section{B. PICTA and PACER}

PACER is an agreement among Australia and New Zealand, on the one hand, and the fourteen countries then comprising the Forum Island Countries 75 (Cook Islands, Federated States of Micronesia, Fiji Islands, Kiribati, Republic of Marshall Islands, Nauru, Niue, Republic of Palau, Papua New Guinea, Samoa, Solomon Islands, Tonga, Tuvalu, and Vanuatu), on the other..$^{6}$ PACER is described as an umbrella agreement under which the Pacific Island Countries Trade Agreement (PICTA)77 and other arrangements fall; it is not intended in and of itself to be a trade agreement that requires notification pursuant to GATT Article XXIV..$^{8}$

At present the agreement is asymmetrical, providing that Australia and New Zealand will maintain "all existing arrangements with respect to market access" for any Forum Island Country until such time as "that particular Forum Island Country has concluded new and/or improved trade arrangements providing equal or better access to" Australia and New Zealand's markets.79 Forum Island Countries are not expected to make any immediate market access concessions to Australia or New Zealand; instead, the agreement contemplates that these countries will integrate among themselves first, in the form of

74 See also Onguglo, "Developing Countries and Unilateral Trade Preferences in the International Trading System," in M. R. Mendoza, P. Low, and B. Kotschwar (eds.), Trade Rules in the Making: Challenges in Regional and Multilateral Negotiations (1999), accessible at http://www.wto.org/English/tratop_e/devel_e/semo1_e/ongugl_e.doc (referring to SPARTECA and GSP as permanent exceptions under the Enabling Clause).

75 The Forum Island countries are also referred to as the Pacific Islands Forum (PIF) members.

${ }^{6}$ The Pacific Islands Forum suspended Fiji from its membership on May 2, 2009. See, e.g., Cordemans, supra note 68.

77 PICTA is an agreement among the Forum Island countries; neither Australia nor New Zealand is a party.

${ }^{8}$ PACER Article 3.7(a) makes this statement: "This Agreement is not intended to be: a customs union, an interim agreement leading to the formation of a customs union, a free trade area, or an interim agreement leading to the formation of a free trade area notifiable under Article XXIV of the General Agreement on Tariffs and Trade." Article 3.7(b) further explains that the agreement is not intended to be an agreement notifiable under Article V of the General Agreement on Trade in Services (GATS).

79 PACER Article 5.3. 
PICTA ${ }^{80}$ However, eight years after PICTA comes into force, negotiations will begin "with a view to establishing reciprocal free trade agreements between the Forum Island Countries and Australia and New Zealand." ${ }^{81}$ Consultations leading to negotiations to form a reciprocal trade agreement with Australia and New Zealand can be triggered earlier, however, if a Forum Island Country enters into a trade agreement (as defined by GATT Article XXIV:8) with a developed non-Forum country with a per capita GDP higher than the lowest per capita GDP of a developed Forum member, ${ }^{82}$ or if all the PICTA countries jointly enter into negotiations to form a trade agreement with one or more nonForum members. ${ }^{8}$ It is these provisions - drafted with the EU's EPA plans in mind - that seem to have served as significant motivation for Australia and New Zealand to negotiate this agreement. ${ }^{84}$

PICTA came into force in 2003 . Accordingly, the Forum Island Countries are to begin consultations with Australia and New Zealand by 2011 with respect to negotiating an FTA. However, should the Pacific ACP states enter into an EPA before then, negotiations with Australia and New Zealand will have to begin at that time. Further complications arise for the three Pacific ACP states (Federated States of Micronesia, Palau, and Marshall Islands) that have a Compact of Free Association with the United States. As with PACER, the Compact requires that the United States should receive market access as favorable as that provided to any other country. ${ }^{85}$ Thus, for these three countries, any EPA assessment must take into account the extension of duty-free access not only to Australia and New Zealand but to U.S. exports as well. ${ }^{86}$

\section{Pacific Islands in the Balance}

The PIF countries now find themselves in a difficult position. Their ACP preferences have expired, leaving them with the choice of negotiating an EPA or relying on alternative sources of preferences. The former is fraught

80 PACER Article 4.1.

81 PACER Article 5.1.

82 PACER Article 6.3(b).

83 PACER Article 6.4.

84 For example, Australia's national interest analysis of PACER emphasizes the benefit of getting MFN treatment if Forum Island countries negotiate an FTA with a developed country with a higher GDP than Australia or New Zealand; see http://www.aph.gov.au/House/ committee/jsct/12March2002/pacernia.pdf.

85 See, e.g., Compact of Free Association between the Federated States of Micronesia and the United States (as amended 2004), Title 2, Art. IV, Section 243.

86 Dearden, "The Interim Pacific Economic Partnership Agreement," DSA European Development Policy Study Group Discussion Paper No. 36 (March 2008), at 4. See also http://www .forumsec.org.fi/_resources/article/files/FAQ\%20\%20PICTA\%2o\&\%20PACER.pdf. 
with difficulty - the EPA should ideally be an agreement that is sufficiently comprehensive to satisfy Article XXIV but not so comprehensive as to trigger obligations under PACER. This is a combination that may not be feasible. ${ }^{87}$ Thus, there is a real risk that if an EPA is entered into, preferential access will also have to be extended to Australia and New Zealand a number of years earlier than it otherwise would. As already noted, Pacific Island countries do not import much from Europe, but they do import significant volumes from Australia and New Zealand. Entering into reciprocal trading arrangements with Australia and New Zealand would entail lowering tariffs on products from these countries, which would have significant consequences for the small local economies. ${ }^{88}$ The other option is to decline to negotiate an EPA. On the export side of things, Europe is not a major export market for most Pacific Island countries; however, they still do not want to lose their preferential access. The EU's GSP scheme does not cover certain important exports for Pacific economies, such as sugar, and it is unlikely it would be willing to dramatically expand its GSP scheme as such preferences have to be offered on a generalized basis to all similarly situated developing countries. ${ }^{89}$ In this way, declining to enter into an EPA would have potential negative consequences for export volumes.

The Pacific Island countries have next to no bargaining power when dealing with their stronger regional partners, Australia and New Zealand. Not only are Australia and New Zealand the main export markets for these economies, but they are the source of many imports. Pacific Island nations receive a great deal of their financial assistance from Australia and New Zealand, and many of their citizens attend school or work (or both) in these developed neighboring countries. Thus, although the PIF countries entered into PACER with New Zealand and Australia, this does not mean all parties saw the agreement as equally beneficial. Indeed, the Forum countries felt significant pressure to

${ }_{77}$ This may not be impossible, however. Whether it is due to poor drafting or intentional design, PACER appears to give some wiggle room to the Forum Island countries to negotiate an agreement with the EU that would not trigger obligations to negotiate with Australia and New Zealand, but only if the EPA covered trade other than goods, i.e., services and investment. Although the EU agreed to begin EPA negotiations within these sectors, it is clear it wants to have goods incorporated into an agreement, whether that be in the form of an EPA or a separate goods arrangement. See Articles 5 and 6 PACER; Kelsey, "Free Trade Agreements Boon or Bane? Through the Lens of PACER," 37 Victoria U. Wellington L. Rev. (2006) 391, at 398-400 (explaining the lack of clarity in these provisions and the implications of the potential interpretations).

${ }^{88}$ Tariffs provide between 20 and 50 percent of government revenue for the Pacific Island countries. See Kelsey, supra note 87 at 412.

89 See "European Communities - Conditions for the Granting of Tariff Preferences to Developing Countries,"WT/DS246/AB/R (April 7, 2004), Appellate Body report. 
enter into PACER. Although the Forum has proven a useful entity for Pacific Island members in the context of their multilateral trade concerns, it is less helpful in the regional context when it is members of the Forum itself Australia and New Zealand - that are pushing difficult decisions. $9^{\circ}$

\section{CONCLUSION}

The multilateral trading system provides a better prospect than do FTAs for weaker countries to obtain meaningful trade access to their stronger trading partners' markets..$^{11}$ Furthermore, weaker countries may be less susceptible to political pressures in the multilateral context where they constitute a majority than in the bilateral or plurilateral setting. Path dependence is also more of a problem in the bilateral-plurilateral context, where "cookie cutter" agreement provisions can easily become default rules. Notwithstanding most WTO members' preference for the multilateral forum, given the uncertain timing and scope for a completed Doha Round, it is likely that the next several years will see members continue to flock to enter into new bilateral and plurilateral arrangements. Developing and developed countries alike, no matter how committed to the WTO in theory, will feel the need to enter into FTAs at a minimum to avoid losing their comparative advantage as their trading competitors pair up with common export target countries..$^{22}$

Unfortunately, as this chapter has shown, the political influence stronger countries can exert in bilateral and plurilateral negotiations not only has direct effects on the weaker parties to the negotiations, but can also have flow-on effects for countries not directly tied to the agreements. Unfavorable provisions arise initially out of the political dominance of stronger negotiating partners such as the United States, the EU, and - relative to the Pacific Australia and New Zealand. Although these provisions are perhaps problematic for the multilateral trading system as they proliferate, in the first instance they

$9^{\circ}$ Bowman, "The Pacific Island Nations: Towards Shared Representation," in P. Gallagher, P. Low, and A. L. Stoler (eds.), Managing the Challenges of WTO Participation (2005), Case Study 33 (discussing the benefits for the Pacific Island WTO members of having the Pacific Islands Forum Representative Office to assist with participating in WTO negotiations and resolving disputes on a regional rather than a country-specific basis).

91 But see Blum, "Bilateralism, Multilateralism, and the Architecture of International Law," 49 Harv. Int'l L. J. (2008) 323, at 339-343 (identifying instances when bilateral settings may be more advantageous for weaker states than multilateral settings).

92 For a discussion of this phenomenon see Lewis, "The Free Trade Agreement Paradox," 21 NZ U. L. Rev. (2005) 554; Lewis, "The Prisoners' Dilemma and Free Trade Agreements: An Application of Game Theory to Trade Liberalization Strategy," in Boulle et al. (eds.), supra note 22 , at $21-39$. 
were accepted by the weaker parties to these trade agreements and thus may seem legitimate. However, as the two examples provided demonstrate, such provisions can have impacts outside the parameters of the original agreement. These negative externalities are not the result of a bargained-for exchange. As FTAs continue to proliferate, we can expect political influence to continue to have ripple effects far beyond the scope of any given agreement. This creates legitimacy concerns, because it is not equitable for FTAs to constrain the policy options of countries that are not party to those agreements, whether through path-dependent externalities of boilerplate provisions or, as demonstrated through the examples of AUSTFA and PACER, through more particularized dynamics existing between trading partners. In contemplating potential reforms to GATT Article XXIV, WTO members should address the fact that political asymmetry in FTA negotiations produces negative externalities on third parties to FTAs, and that these externalities further undermine the legitimacy of such agreements in general. 